LIVERPOOL.-The University has been bequeathed the sum of $20,000 l$. by the late Mr. Richard Braithwaite, of Liverpool.

MANChEster.-Dr. J. K. Charlesworth has resigned the senior lectureship in geology as from December 25, 1921, upon his appointment to the chair of geology in the University of Belfast.

The following appointments have been made:Mr. J. S. Wrigley, assistant lecturer in engineering; Dr. R. A. Webb, demonstrator in pathology; Mr. J. H. Blackaby, assistant lecturer in physics; $\mathrm{Mr}$. Arthur Adamson, lecturer in physics in the faculty of technology; and Mr. H. N. Mercer, assistant lecturer in physics in the faculty of technology.

OxFORD.-The following elections and appointments have been made at Balliol College : Dr. J. W. Nicholson, lately professor of mathematics in the University of London, King's College, to a War Memorial Fellowship as tutor in mathematics and physics; Mr. A. O. Ponder, Rhodes Scholar, to a lectureship in chemistry, and Mr. C. R. Morris to a lectureship in philosophy.

ShEFField.-The following appointments have been made by the Council: Mr. H. P. Lewis, assistant lecturer in geology during the absence of the professor; Mr. E. H. Eastwood, demonstrator in pathology and bacteriology in succession to Dr. N. E. Challenger; and Mr. A. J. Chappell to be assistant lecturer in mechanical engineering.

MR. L. Bolton, winner of the roool, prize offered by the Scientific American for the best essay on Einstein's theory, will give two lectures on "Relativity" at Birkbeck College, Fetter Lane, E.C.4, on Mondays, October 24 and $3 \mathrm{I}$, at 5.30. Admission is free, without ticket.

IN connection with the paper-making classes at the Battersea Polytechnic, a film showing "The Manufacture of Newspaper in Canada-from Standing Timber to Finished Sheet," will be displayed under the auspices of the Technical Section of the Paper Makers' Association of Great Britain and Ireland on Monday next, October 24, at 7.15 p.m. Admission is free to all interested in the paper trades.

The first Report of the British Association Committee on Training in Citizenship has been published in pamphlet form, and can be obtained from the Secretary, Io Moreton Gardens, S.W.5 (single copies, $x s$. each, $9 s$. per dozen, $3 l$. per hundred). The report contains the syllabus of a text-book of civics, Lord Lytton's scheme for organising regional study, notes of lessons on regional survey, and schemes for training adopted in some county council schools.

IN celebration of the four hundredth anniversary of Cambridge printing a dinner will be given by the Vice-Chancellor and the Syndics of the University Press on November to in the hall of Corpus Christi College. It is stated in the University Calendar that the rights of the University in connection with printing date from 1534 , but the acquisition of the present site of the Press began in 1762 and the erection of the existing buildings in 1804. The building known as the Pitt Press, which faces Trumpington Street, was completed in $1832^{\circ}$ from part of the funds raised to establish a memorial to the younger Pitt. With reference to the early date at which the University acquired printing rights, it is interesting to note that it was only in 1476 , about sixty years previously, that William Caxton set up, the first printing press in England, in the precincts of Westminster. Abbey.

\section{Calentar of Scientific Pioneers.}

October 20, 1896. François Félix Tisserand died.Prominent among French astronomers of last century for his researches in mathematical astronomy, Tisserand was called to the Paris Observatory by Leverrier, in 1878 succeeded to Leverrier's chair in the Academy of Sciences, and in 1892 followed Mouchez as director of the observatory. It has been said his "Traité de Mécanique Céleste" is worthy to stand beside the " Mécanique Céleste" of Laplace.

October 20, 1894. Charles Garpmael died.-A fellow of St. John's College, Cambridge, and a writer of mathematical papers, Carpmael settled in Toronto in 1872 , and became head of the Canadian weather service. In $188_{5}$ he was President of the Canadian Royal Society.

October 21, 1886. Frederick Guthrie died.-Trained in England and Germany as a chemist, Guthrie turned his attention to physics, became professor at the Royal College of Science, and in 1874 took the initiative in founding the Physical Society.

October 22, 1871. Sir Roderick Impey Nurchison died.-Originally a military officer, Murchison began his career as a man of science at the age of thirty. A great geological observer, his name is especially associated with the Silurian system, and with the geological survey of Russia. He foreshadowed the discovery of gold in Australia. In 1855 he succeeded De la Beche as director of the Geological Survey of Great Britain, and he was the founder of the chair of geology at Edinburgh.

October 23, 1841. Johan August Arfvedson died.A member of the Stockholm Academy of Sciences, Arfvedson wrote much on minerals, and in 1817 discovered the metal lithium.

October 24, 1601. Tycho Brahe died.-Noble by birth and rich by inheritance, Tycho alienated his family by his devotion to astronomy, but secured the friendship of Frederick, King of Denmark, who gave him the island of Hven, and enabled him to build the most splendid observatory ever seen. Here for twenty years Tycho and his assistants observed the heavens with an accuracy hitherto unknown. From various causes, in ${ }^{5} 597$ the observatory was aban? doned, and Tycho migrated to Prague, where Kepler became one of his assistants.

October 24, 1655. Pierre Gassendi died.-.Theologian, philosopher, mathematician, and astronomer, Gassendi was a provost at the cathedral at Digne, and in 1645 accepted the chair of mathematics in the College Royal in Paris, where he enjoyed a European reputation. He was the first to observe a transit of Mercury.

October 24, 1873. rrederick Grace calvert died.An assistant to Chevreul, and afterwards a manu facturer in Manchester, Calvert carried out many chemical researches, and to him is mainly due the use of carbolic acid as a disinfectant and for therapeutic purposes.

October 24, 189\%. Robert ctrant died.-The author of a valuable history of physical astronomy, Grant, in I859, succeeded Nichol as professor of astronomy at Glasgow. Among his labours was the compilation of two catalogues of stars, one published in $188_{3}$, containing $64{ }^{1} 5$ stars, and the second, published in 1892 , containing 2156 stars.

October 25, 1647. Evangelista Torricelli died.-The first to demonstrate the pressure of the atmosphere and the inventor of the barometer, Torricelli after the death of Galileo in 1642 bmame mathematician to the Grand Duke of Tuscany: $\quad$ E. C. S. 